\title{
Late Miocene ostracods from the Fujikotogawa Formation, northern Japan - with reference to cold water species involved with trans-Arctic interchange
}

\author{
TOSHIAKI IRIZUKI \\ Department of Earth Sciences, Aichi University of Education, Kariya 448, Japan.
}

\begin{abstract}
Seventy-eight ostracod species belonging to 38 genera are recognized from the late Miocene Fujikotogawa Formation (c. $7-8 \mathrm{Ma}), 40 \mathrm{~km}$ NE of Akita City, northern Japan. Some $30-40 \%$ of the ostracod species belong to the cold water groups (circumpolar and cryophilic species) reported from Plio-Pleistocene formations yielding the Omma-Manganji Fauna, the name given by Otuka (1939) to the Pliocene Japanese cold water molluscan fauna. This study demonstrates that most ostracod species distinguished in deposits yielding the Omma-Manganji Fauna had already appeared in the late Miocene. At least 13 of the ostracod species have been reported from both the Arctic and northern Atlantic Oceans, implying migration from the Pacific to the northern Atlantic through the Arctic after the Bering Strait had been breached. The 1.3 circumpolar, nine cryophilic and four endemic cold water species are illustrated, with brief taxonomic notes. J. Micropalatontol. 13(1): 3-15, Scptember 1994.
\end{abstract}

\section{INTRODUCTION}

One of the most significant geological events in the late Neogene of high northern latitudes is the Pliocene opening of the Bering Strait. It is thought to have brought about a drastic faunal change in northern oceans. In order to investigate the dynamics of ostracod species in relation to the opening of the Bering Strait, it is important to compare Miocene to Recent ostracod assemblages from Arctic, northern Atlantic and northern Pacific Provinces. Ostracod species inhabiting such frigid to cold water environments as the Arctic and northern Atlantic have been reported long since by many workers. In recent years, Hazel $(1967,1970)$ and Hazel \& Valentine (1969) investigated detailed distributions of many ostracod species from off northeastern North America; Neale \& Howe (1973, 1975) studied ostracod assemblages from high latitude seas such as Novaya Zemlia; Siddiqui \& Grigg (1975) investigated Recent ostracods from Nova Scotia, North America and Canada; Penney (1989) investigated Recent ostracods of the Ikerssuak (Bredefjord) District in southwestern Greenland; Hartmann (1992) reported living and subfossil ostracods of the Liefdefjorden (North Spitsbergen). Late Neogene fossil ostracods in eastern North America, northern Europe, and the Arctic have also been studied by a large number of workers (Swain, 1963; Hazel, 1968; Cronin, 1981, 1988, 1991a, b; Cronin \& Dowsett, 1990; Marincovich et al., 1990; Brouwers et al., 1991).

On the other hand, in northern Japan many cold water ostracod species have been reported by many workers from Plio-Pleistocene formations yielding the Omma-Manganji Fauna, which was assigned to cold water fossil molluscan assemblages in the Pliocene of the Japan Sea side by Otuka (1939). Hanai (1957a, b, c, 1959a, b, 1970) conducted the taxonomic work of typical high latitude genera such as Palmenella, Cythere and Semicytherura from the PlioPleistocene Setana and Sawane Formations ( $a$ and $\mathrm{e}$ in Fig. 1). Okada (1979) and Ishizaki \& Matoba (1985) showed some cold water ostracods from Plio-Pleistocene formations in Akita Prefecture. Tabuki (1986) recognized some genera and species, reported from the north Atlantic to Arctic Provinces, in the Plio-Pleistocene Daishaka Formation ( $\mathrm{c}$ in Fig. 1). Hanai \& Yamaguchi (1987) also found those species in the early Pleistocene Hamada Formation (b in Fig. 1). Cronin \& Ikeya (1987) presented a preliminary report of ostracod assemblages from the representative formations yielding the Omma-Manganji Fauna and distinguished three different species groups: 26 circumpolar and 21 cryophilic species in the northwestern Pacific, and the remaining temperate endemic species. Hayashi (1988) discussed a palaeoenvironment during deposition of the Plio-Pleistocene Setana Formation by means of fossil ostracod assemblages. Irizuki (1989b) investigated ostracods from the late Pliocene Sasaoka Formation (d in Fig. 1) and suggested that $20-40 \%$ of the assemblages were species inhabiting cold waters. Ishizaki et al. (1993) reported ostracod assemblages from the Omma Formation distributed in the type locality ( $\mathrm{f}$ in Fig. 1) and delineated vertical environmental changes during early to middle Pleistocene time. As a result, some of these ostracod species in the Plio-Pleistocene are common to those in the Arctic and north Atlantic, which suggests that species in the Arctic and/or those in the northwestern Pacific migrated through the Bering Strait.

In Japan, only a few attempts have so far been made at the study of ostracod assemblages of pre-opening of the Bering Strait. The Fujikotogawa Formation is almost the only deposit yielding abundant late Miocene shallow water calcareous fossils on the Sea of Japan side of northern Japan. The purpose of the present study is to report some ostracod species which inhabit the Arctic and northern Atlantic and had already appeared during late Miocene time (pre-opening of the Bering Strait) in the northwestern Pacific and to discuss the origin of such cold water ostracods and their migration during the late Neogene.

\section{GEOLOGICAL SETTING}

The Fujikotogawa Formation is located approximately $40 \mathrm{~km} \mathrm{NE}$ of Akita City, northern Japan (Figs 1 \& 2); its 


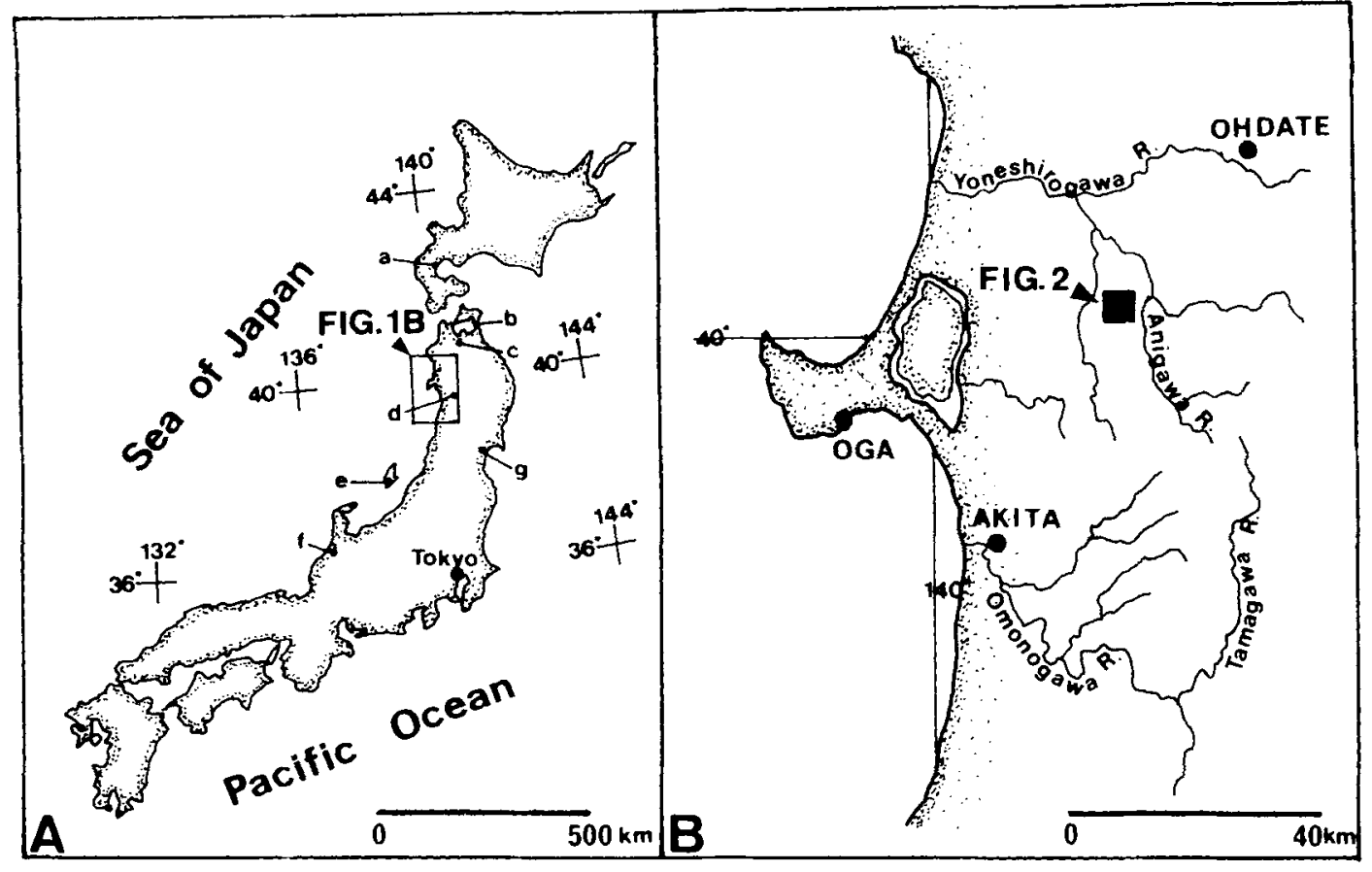

Fig. 1. Locality of the Fujikotogawa Formation, some Plio-Pleistocene formations yielding the Omma-Manganji Fauna (a to $f)$ and the Tatsunokuchi Formation (g). a: Setana Formation: b: Hamada Formation; c: Daishaka Formation; d: Sasaoka Formation; e: Sawane Formation; f: Omma Formation.

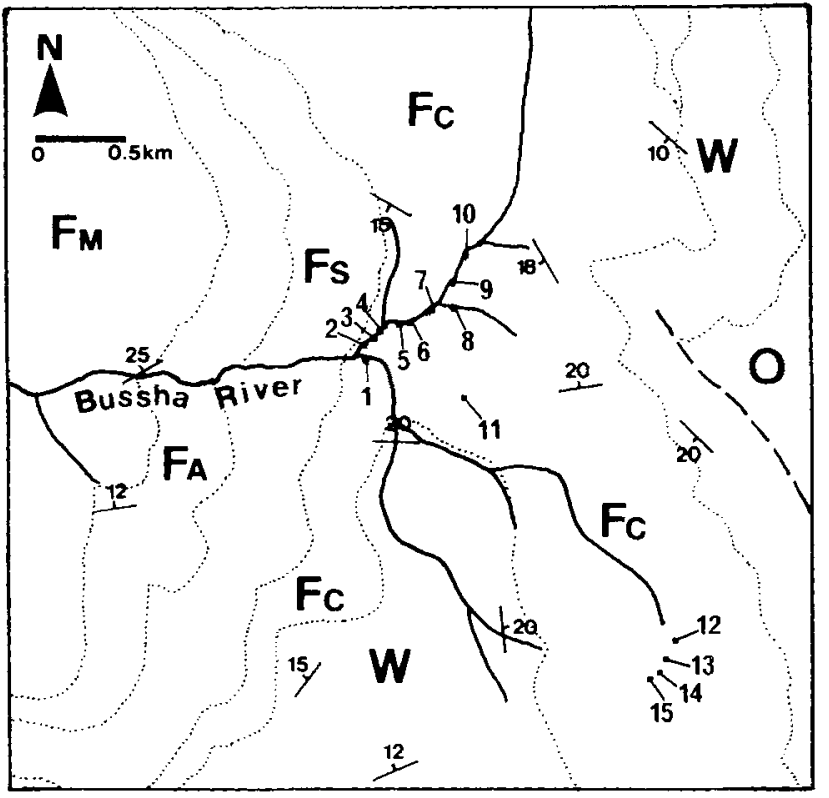

Fig. 2. Map showing the geology and sample localities of the Fujikotogawa Formation. O: Obinai Formation; W: Iwaya Formation; F: Fujikotogawa Formation (FC: calcareous sandstone; FS: fine sandstone; FA: alternations of sandstone and mudstone; FM: mudstone). Revised from Sumi \& Moritani (1973).

geology was investigated in detail by Sumi \& Moritani (1973) and Ogasawara et al. (1986). It overlies conformably the Iwaya Formation. The Lower Fujikotogawa Formation can be divided into four parts on the basis of lithology: a lower part consisting of fine to medium calcareous black sandstone yielding many calcareous fossils (FC in Fig. 2); this is succeeded by fine sandstone (FS); followed by alternations of sandstone and black mudstone (FA); the upper part consists of black mudstone rich in siliceous fossils (FM). The lower Fujikotogawa Formation is assigned to the late Miocene and correlated with the Funakawa Formation distributed around Akita City. Saito \& Izawa (1988) reported such planktonic foraminifers as Globorotalia praemargaritae Catalano \& Sprovieri and Globorotaloides falconarae Giannelli \& Salvatorini, which indicate zone N.17 of Blow (1969) from the Fujikotogawa Formation. Izawa (pers. comm.) reported a nannofossil species, Discoaster quinqueramas Gartner, showing zone CN 9 of Okada \& Bukry (1980) from sandstones of the lower part (near sample FC-11). The age of the lower part of this formation is thus suggested to be $7-8 \mathrm{Ma}$.

\section{MATERIALS AND METHODS}

Fifteen rock samples were collected from the lowest part of the Fujikotogawa Formation (FC in Fig. 2). However, only five samples yielded sufficient numbers of ostracod specimens for study (FC-11 to 15) (Fig. 2). Eighty-gram sediments were disaggregated by using a saturated sodium sulfate solution and naphtha, washed through a 200 mesh sieve screen, and dried. A fraction coarser than $125 \mu \mathrm{m}$ (115 mesh) was sieved and divided by a sample splitter into aliquot parts, from which 200-odd specimens of ostracods were picked and placed on an assemblage slide.

\section{FOSSIL OSTRACOD ASSEMBLAGES}

Seventy-eight ostracod species belonging to 38 genera were discriminated in the five samples (calcareous fine sandstone) of the lower Fujikotogawa Formation (Table 1), but many 


\begin{tabular}{|c|c|c|c|c|c|c|}
\hline Fossil ostracods from the Fujikotogawa F & $\begin{array}{l}\mathrm{FC} \\
11\end{array}$ & $\begin{array}{l}\overline{\mathrm{FC}} \\
12\end{array}$ & $\begin{array}{l}\mathrm{FC} \\
13\end{array}$ & $\begin{array}{l}\mathrm{FC} \\
14\end{array}$ & $\begin{array}{l}\text { FC } \\
15\end{array}$ & \\
\hline * Acanthocythereís dunelmensis (Norman) & & 1 & 1 & 1 & 2 & 5 \\
\hline Aurila of corniculata okubo & 9 & 3 & & 3 & 3 & 18 \\
\hline Aurila sp. A & 7 & 11 & 4 & 6 & 6 & 34 \\
\hline +Baffinicythere sp. 1 & 1 & & & & & 1 \\
\hline +Baffinicythere sp. 2 & 1 & 1 & & & 2 & 4 \\
\hline Callistocythere setanensis Hanai & 1 & 1 & & 1 & & 3 \\
\hline Call istocythere undulatifacialis Hanai & 3 & 1 & 3 & 2 & 1 & 10 \\
\hline Callistocythere sp. & & & & 1 & & 1 \\
\hline Caudites? posterocostata (Ishizaki) & 6 & 13 & 7 & 4 & 9 & 39 \\
\hline * Cluthia cluthae Neale & & & & 1 & & 1 \\
\hline Corrucoquimba moniwensis (Ishizaki) & 6 & 3 & 2 & 3 & 4 & 18 \\
\hline Corrucoquimba cf. saitoi (Ishizaki) & 12 & 4 & 2 & 4 & 1 & 23 \\
\hline cythere kamikoaniensis Tsukagoshi \& Ikeya & 9 & 37 & 35 & 15 & 35 & 131 \\
\hline Cythere? sp. & & & 1 & & & 1 \\
\hline * Cytheropteron ef. angulatum Brady \& Robertson & 1 & & & 1 & 1 & 3 \\
\hline * Cytheropteron cf. arcticum Neale \& Howe & 4 & 3 & 5 & & 3 & 15 \\
\hline Cytheropteron eremitum Hanai & & & & & 2 & 2 \\
\hline Cytheropteron miurense Hanai & & 2 & 6 & & 1 & 9 \\
\hline * cytheropteron cf. nodosoalatum Neale \& Howe & & 1 & & & & 1 \\
\hline Cytheropteron Sawanense Hanai & 11 & 32 & 33 & 22 & 26 & 124 \\
\hline Cytheropteron sp. & & & & & 1 & 1 \\
\hline * Elof sonella concinna (Jones) & 1 & 4 & 2 & 3 & & 10 \\
\hline Eucythere sp. & & & & 1 & & 1 \\
\hline Eucytherura neoalae (Ishizaki) & 3 & 2 & & 1. & 1 & 7 \\
\hline Falsobuntonia of. taiwanica Malz & 1 & & & & & 1 \\
\hline +Fimarchinella daishakaensis Tabuki & 2 & & 1 & & 3 & 6 \\
\hline + Finnarchinel la hanai i okada & 1 & 2 & 5 & 4 & 4 & 16 \\
\hline * F tinarchineila japonica (Ishizaki) & 29 & 47 & 25 & 9 & 15 & 125 \\
\hline Haniaborchella triangularis (Hanai) & & 1. & & & & 1 \\
\hline * Hemicythere emarginata (Sars) & & & 1 & & 1 & 2 \\
\hline +Hemicy there aff. gurjanovae Schornikov & 45 & 26 & 16 & 22 & 39 & 148 \\
\hline +Hemicythere kitanipponica (Tabuki) & 25 & 11 & 26 & 16 & 18 & 96 \\
\hline + Hemicythere ochotensis Schornikov & 1 & 5 & 4 & & & 10 \\
\hline * llemicytherura clathrata (Sars) & & & & 1 & & 1 \\
\hline * Hemicytherura cf. clathrata (Sars) & & & & & 1 & $\mathrm{l}$ \\
\hline Hemicytherura cuneata Hanai & 2 & 3 & 3 & 3 & 3 & 14 \\
\hline Howeina neoleptocytheroidea (Ishizaki) & 10 & 10 & 9 & 8 & 4 & 41 \\
\hline +Kotoracythere sp. & 1 & 9 & 2 & & 2 & 14 \\
\hline Loxoconcha subkotoraf'orma Ishizaki & 3 & 6 & & & & 9 \\
\hline Loxoconcha sp. & & 2 & & 3 & & 5 \\
\hline Loxocorniculum kotoraformum 1shizaki & 8 & 9 & 9 & 4 & 5 & 35 \\
\hline Loxocorniculum sp. 1 & 17 & 6 & 4 & 10 & 6 & 43 \\
\hline Loxocorniculum sp. 2 & 1 & 1 & & & & 2 \\
\hline * Munseyella hatatatens is Ishizaki & & 1 & 3 & & & 4 \\
\hline Munseyella japonica (Hanai) & 2 & 1 & & & & 3 \\
\hline Neomonoceratina japonica (Ishizaki) & & 3 & & & & 3 \\
\hline Neonesidea sp. & & & & & 1 & 1 \\
\hline Pacambocythere sp. & & & & 1 & & 1 \\
\hline * Pámenel la limicola (Norman) & 3 & 3 & 2 & & 2 & 10 \\
\hline Palmoconcha saboyamensis (Ishizaki) & 2 & & 3 & 2 & 1 & 8 \\
\hline Paracytheridea neolongicaudata Ishizaki & 1. & 10 & 6 & 9 & 3 & 29 \\
\hline Patagonacythere sp. 1 & 1 & & & & & 1. \\
\hline Patagonacythere sp. 2 & & & 1 & & & 1. \\
\hline Pectocythere daishakaensis Tabuki & 1 & & & & & 1 \\
\hline + Robertsonites hanail Tabuki & & 2 & & & & \\
\hline + Robertsonites reticuliforma (Ishizak1) & & 2 & 1 & 3 & 11 & 17 \\
\hline Rotundracy there? sp. & 10 & 1 & 16 & 3 & 12 & 42 \\
\hline Schizocy there kishinouyei (Kajiyama) & 23 & 46 & 31 & 23 & & 123 \\
\hline Semicytherura henryhowei Hanai \& Ikeya & 8 & 7 & 7 & 7 & 10 & 39 \\
\hline Semicytherura aff. henryhowei Hanai \& Ikeya & & 5 & 1 & 1 & & 7 \\
\hline Semicytherura cf. hiberna okubo & & 2 & 4 & & 1 & 7 \\
\hline * Semicytherura maínensis (Hazel \& Valentine) & 4 & 5 & 7 & 4 & 3 & 23 \\
\hline Semicytherura skippa (Hanai) & 1 & & & & & 1 \\
\hline * Semicytherura subundata (Hanai) & 5 & 7 & 10 & 5 & 7 & 34 \\
\hline Semi cy therura sp. 1 & & 2 & & 1 & & 3 \\
\hline Semicy therura sp. 2 & 1 & 2 & 2 & 1 & 4 & 10 \\
\hline Semicytherura sp. 3 & 2 & 8 & 5 & 4 & 7 & 26 \\
\hline Semicytherura sp. 4 & 5 & 9 & 3 & 7 & 5 & 29 \\
\hline Semicytherura sp. 5 & 2 & 9 & 14 & 2 & 13 & 40 \\
\hline Sem i cy therura sp. 6 & 1 & & 1 & & & 2 \\
\hline Semi cytherura? sp. & 1 & & & & & 1 \\
\hline Typhlocy there sp. & & & & 1 & 1 & 2 \\
\hline Urocy thereis? gorokuensis Ishizaki & 2 & 2 & 1 & 3 & & 8 \\
\hline Urocythereis? cf. gorokuensis lshizaki & & 2 & & & 1 & 3 \\
\hline Urocythereis? sp. & & 1 & 3 & & & 4 \\
\hline Xestoleberjs sp. 1 & 1 & 1 & & & & 2 \\
\hline Xestoleberis sp. 2 & 3 & & & & & 3 \\
\hline Gen. et sp. indet. & & & & 1 & 1 & 2 \\
\hline number of specimens & 300 & 388 & 327 & 227 & 282 & 1524 \\
\hline number of species & 50 & 53 & 44 & 44 & 45 & 78 \\
\hline number of circumpolar species & $\overline{49}$ & 72 & 56 & 25 & 35 & 237 \\
\hline number of cryophilic species & 77 & 58 & 55 & 45 & 79 & 314 \\
\hline number of other species & 174 & 258 & 216 & 157 & 168 & 973 \\
\hline
\end{tabular}

Table 1. Ostracod species from the late Miocene Fujikotogawa Formation.

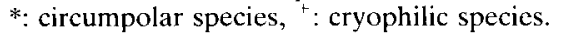




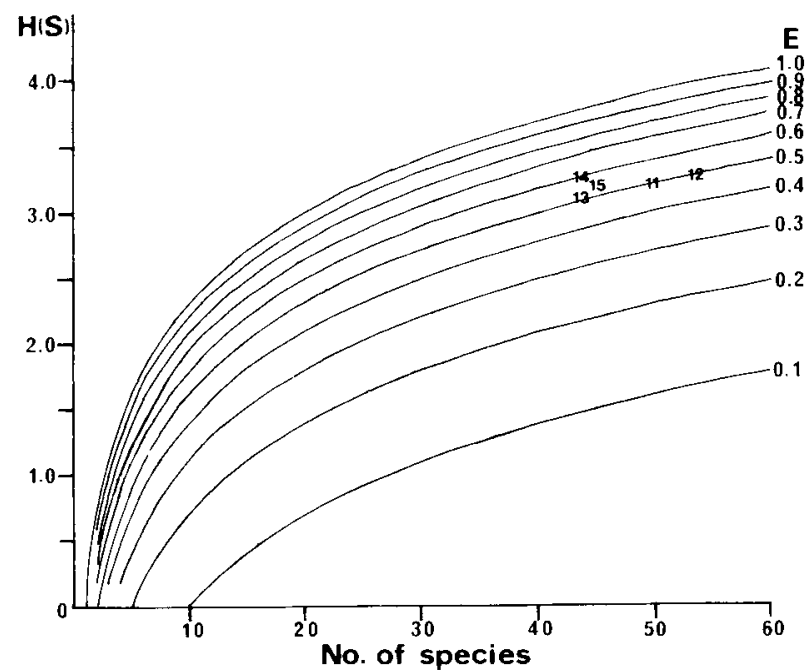

Fig. 3. Diagram showing the projection of samples from the Fujikotogawa Formation, in relation to the number of species, species diversity $(H(S))$, and cquitability $(E)$.

specimens were poorly preserved. There were 44 to 53 species per sample. In order to determine the structure of the ostracod assemblages, the Shannon-Weaver's information function, revised by Buzas \& Gibson (1969), was used. Diversity $H(S)$ and equitability $(E)$ are determined by the following formulae:

$$
H(S)=-\sum p_{i} \ln p_{i} \text { and } E=\mathrm{e}^{I /(S)} / S,
$$

where $p_{i}$ means the proportion of the $i$ th species in a sample, and $S$ the number of species. The latter equation equals the formula $H(S)=\ln (S \cdot E)$, which plots the relationships among the number of species, diversity and equitability on a graph (Fig. 3). Ishizaki (1979), Ishizaki \& Tanimura (1985) and Irizuki (1989b) used this method to interpret depositional environments by means of ostracod faunal structures. Diversity and equitability of fossil ostracod assemblages from the Fujikotogawa Formation were relatively high (Table 1; Fig. 3). Recent ostracod death assemblages in some bay areas have lower values of diversity and equitability (Ishizaki, 1979), whereas those in open sea areas have higher values (Ishizaki, 1979; Irizuki, 1989a; Ikeya \& Itoh, 1991; Ikeya \& Suzuki, 1992). For example, recent ostracod assemblages on the sublittoral $(60-90 \mathrm{~m}$ in depth) sandy bottom of Toyama Bay, central Japan, show a diversity value of about 3.5 and equitability of 0.6 (Irizuki, 1989a). These values approximate those of the Fujikotogawa Formation. Thus, ostracod assemblages from the Fujikotogawa Formation may represent an open sublittoral setting. Dominant species are Schizocythere kishinouyei, Hemicythere aff. gurjanovae (= Hemicythere gurjanovae of Cronin \& Ikeya, 1987), Finmarchinella japonica, Cytheropteron sawanense and Cythere kamikoaniensis. The total number of specimens of these species is more than 100 . These species are also representative of sublittoral open seas. On the other hand, Ogasawara et al. (1986) reported some benthic foraminifers having various depth ranges (inner sublittoral to upper bathyal) from the lower Fujikotogawa Formation, thus there is a possiblity that those fossil assemblages include displaced specimens from shallower areas.

Cronin \& Ikeya (1987) recognized 26 circumpolar species which are known as fossil and/or inhabitants in high-latitude northern hemisphere seas, and 21 cryophilic species typically occurring with circumpolar species in Plio-Pleistocene formations of northeastern Japan. In the present study, at least 13 circumpolar and ten cryophilic species were recognized from the Fujikotogawa Formation. Previously, three circumpolar species (Finmarchinella japonica $=$ Finmarchinella angulata of Cronin \& Ikeya, 1987, Munseyella hatatatensis Ishizaki $=$ Munseyella mananensis (Hazel \& Valentine), and Palmenella limicola (Norman)) and four cryophilic species (Finmarchinella hanaii, Finmarchinella nealei, Hemicythere kitanipponica $=$ Hemicythere? sp. of Yajima (1988) and Robertsonites reticuliforma) were reported from some Miocene formations (Ishizaki, 1966; Yajima, 1988). According to Yajima (1988), Finmarchinella hanaii and Palmenella limicola appeared in Blow's planktonic foraminiferal zone N. 9 (early Middle Miocene). Finmarchinella japonica (Cronin \& Ikeya (1987) thought that Finmarchinella japonica is conspecific to Finmarchinella angulata (Sars)) was reported from the Hatatate Formation corresponding to N. 13 zone (middle Middle Miocene) (Ishizaki, 1966). Ten circumpolar species are as follows: Acanthocythereis dunelmensis, Cytheropteron cf. nodosoalatum, Elofsonella concinna, Finmarchinella japonica (Finmarchinella angulata of Cronin \& Ikeya, 1987), Hemicythere emarginata, Hemicytherura clathrata, Munseyella hatatatensis, Palmenella limicola, Semicytherura mainensis and Semicytherura subundata. Additionally, Cytheropteron cf. angulatum (= Cytheropteron tsugaruense Tabuki, 1986), Cytheropteron cf. arcticum, and Cluthia cluthae also inhabit the Arctic and north Atlantic (Neale, 1973; Neale \& Howe, 1973, 1975; Whatley \& Masson, 1979). Ten cryophilic species are as follows: Baffinicythere sp. 1, B. sp. 2, Finmarchinella daishakaensis, F. hanaii, Hemicythere aff. gurjanovae, H. kitanipponica, H. ochotensis, Kotoracythere sp., Robertsonites hanaii and $R$. reticuliforma. Baffinicythere sp. 1 and $B$. sp. 2 are very closely related to $B$. howei Hazel. Irizuki (in prep.) discusses the morphological relationships among species of the genus Baffinicythere. All these lines of evidence indicate that many high latitude species lived around northern Japan during the late Miocene. Figure 4 shows the percentages of circumpolar, cryophilic and temperate species in each sample from the Fujikotogawa Formation. All samples contain about $30-40 \%$ cold water ostracod species (circumpolar + cryophilic species of Cronin \& Ikeya (1987) and this study). Many diversified species of the genus Semicytherura closely related to $S$. undata, which lives around the Arctic (Neale \& Howe, 1975; Siddiqui \& Grigg, 1975; Penney, 1989), occur in the Fujikotogawa Formation (Pl. 3). All these species can be recognized in the Omma-Manganji Fauna suggesting cold water environments in the Pliocene of Japan (Cronin \& Ikeya, 1987). Such species as Callistocythere setanensis, Cytheropteron sawanense, Howeina neoleptocytheroidea, 


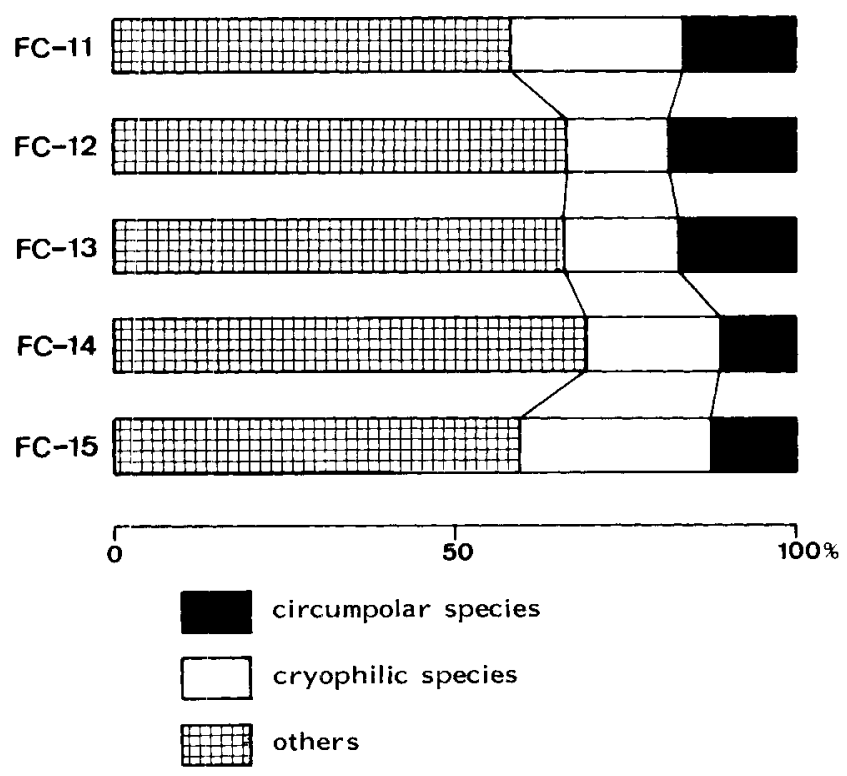

Fig. 4. Diagram showing the percentages of circumpolar, cryophilic, and temperate species in samples from the Fujikotogawa Formation.

Patagonacythere sasaokensis and Urocythereis? gorokuensis are endemic or are confined to a cold water environment in northern Japan. It is true, however, that there coexist such warm water species as Falsobuntonia cf. taiwanica, Loxocorniculum spp., Pacambocythere sp., Paracytheridea neolongicaudata and Typhlocythere sp. They live in shallow water under the influence of the warm Kuroshio and Tsushirna Currents.

\section{DISCUSSION}

Extensive studies on the origin of the molluscan Omma-Manganji Fauna and its migration have been made by many workers (e.g. Ogasawara, 1986). Durham \& MacNeil (1967) cited more than 125 megainvertebrates of Pacific origin which entered the Arctic-Atlantic region, while only 16 Arctic--Atlantic taxa occur widely in the North Pacific late Neogene strata. Recently, Vermeij (1991) identified 295 molluscan species that either took part in the trans-Arctic interchange or are derived from stocks that so did, and suggested that out of these species, 261 are of Pacific origin, whereas only 34 are of Arctic-Atlantic origin. The first appearance of Pacific molluscs in the Atlantic region has been reported from a late Pliocene formation (Serripes groenlandicus zone) in Iceland, which is correlated to the Red Crag of England (MacNeil, 1973; Gladenkov, 1981). MacNeil (1973) mentioned that the northern Atlantic Ocean was abnormally cool in preglacial time and that the earliest migration of Pacific molluscs across the Arctic, and probably the first opening of the Bering Strait, took place in late Miocene time and the first great migration took place in early Pleistocene time. The date of the first opening of the Bering Strait is now problematical, but it is considered in general to have been about $3.0 \mathrm{Ma}$ (Marincovich et al., 1990). More recently, Gladenkov et al. (1991) studied the stratigraphy and palacoceanography of Pliocene deposits of Karaginsky Island, off eastern Kamchatka, Russia, and concluded on account of the occurrence of several marine species of Arctic and Atlantic origin in contemporary deposits that the proto-Bering Strait may have opened, at least temporarily, by $4.0 \mathrm{Ma}$. They suggested, in addition, that a second migration of marine species occurred about 3.6-3.2 Ma which is coeval with the migration of many marine species from the Pacific to the Atlantic through the Arctic. Cronin (1991b) investigated fossil ostracods from Tjörnes, Iceland, and mentioned that the first appearance of a Pacific species, Palmenella limicola, was found in the Cytheridea zone (molluscan Serripes zone) assinged to $2.8 \mathrm{Ma}$. This is concordant with the result from the molluscan study of MacNeil (1973). Moreover, he mentioned that such high latitude ostracods as Robertsonites tuberculata (Sars), Elofsonella concinna, Acanthocythereis dunelmensis, Palmenella limicola and Finmarchinella spp. occur in pre-3.0 Ma deposits of the Limimtevayamian suite of Karaginsky Island, off eastern Kamchatka, Russia. He pointed out that these species migrated through the Arctic into the Atlantic once the Bering land barrier was breached. According to the ostracod list given by Gladenkov et al. (1991), the Limimtevayamian suite contains some ostracods common to the Fujikotogawa Formation. The present study supports the possibility that Acanthocythereis dunelmensis, Elofsonella concinna and Palmenella limicola migrated from the Pacific to the Arctic. In addition, other species such as Cytheropteron cf. arcticum, Cytheropteron cf. nodosoalatum, Hemicythere emarginata, Hemicytherura clathrata, Semicytherura mainensis, Semicytherura subundata and Munseyella hatatatensis are thought to have migrated to the Arctic-Atlantic Provinces through the Bering Strait. Some hemicytherin ostracods such as Baffinicythere howei, some Finmarchinella species (e.g. F. logani (Brady \& Crosskey), $F$. barentzovoensis (Mandelstam), etc.) and Hemicythere villosa (Sars), are representative species ranging in age from late Pliocene (e.g. Red Crag of England, Tjornes in Iceland) to Recent in the Arctic and northern Atlantic Provinces, but they have never been reported from northeastern Japan. Several different congeneric species are found in the late Miocene Fujikotogawa Formation, which suggests that some species migrated from the northwestern Pacific to the Arctic-Atlantic to evolve into new species after 3.0 Ma.

Whether water temperature around northeastern Japan at the time when the Fujikotogawa Formation was deposited (about 7-8 Ma) was warmer or colder than today is yet to be determined. This question will be dispelled by further investigations in combination with isotope measurements.

Fossil assemblages from the Fujikotogawa Formation are correlated with those from Plio-Pleistocene formations yielding the Omma-Manganji Fauna based on Cronin \& Ikeya (1987), Hayashi (1988), Ishizaki \& Matoba (1985), Irizuki (1989b), Okada (1979), Tabuki (1986) and unpublished data. About $90 \%$ of ostracod species from the Fujikotogawa Formation are common to those of PlioPleistocene formations. This indicates that the species composition of the Fujikotogawa Formation is very similar to that of Plio-Pleistocene sediments yielding the Omma- 
Manganji Fauna, but generally the ratio of circumpolar and cryophilic species is higher in Plio-Pleistocene deposits than that in the Fujikotogawa Formation (see Cronin \& Ikeya, 1987).

\section{CONCLUSIONS}

The late Miocene Fujikotogawa Formation yields important ostracod species for discussing the origin of cold water ostracod faunas and their migration. Major conclusions from the present study are as follows:

1. At least 13 sublittoral species from the Fujikotogawa Formation are found in the Arctic and northern Atlantic, suggesting migration from the Pacific through the Bering Strait (Table 1).

2. Atlantic species belonging to three hemicytherin genera, Baffinicythere, Finmarchinella and Hemicythere, may be descended from Pacific ancestors.

3. Ostracods such as Hemicythere and Semicytherura were already diversified during the late Miocene and most ostracod species from the Fujikotogawa Formation are found common to the Plio-Pleistocene of northern Japan.

\section{TAXONOMIC NOTES}

Some aspects of 13 circumpolar $(*)$, nine cryophilic $(+)$ and four endemic cold water species $(-)$ are briefly discussed below. Specimens are deposited in the Department of Geoenvironmental Science, Faculty of Science, Tohoku University (IGPS).

\section{Suborder Podocopina Sars, 1866 \\ Family Cytherideidae Sars, 1925 \\ Genus Kotoracythere Ishizaki, 1966 + Kotoracythere sp.}

(Pl. 1, fig. 1)

Remarks. This species has been widely reported from the Plio-Pleistocene formations in northern Japan (Ishizaki \& Matoba, 1985; Tabuki, 1986; Cronin \& Ikeya, 1987).

Genus Munseyella van den Bold, 1957

* Munseyella hatatatensis Ishizaki, 1966

(Pl. 1, fig. 2)

Remarks. Cronin \& Ikeya (1987) thought that $M$. hatatatensis is conspecific with $M$. mananensis Hazel \& Valentine, 1969. M. hatatatensis was first described from the Middle Miocene (Blow's (1969) N. 13) Hatatate Formation in Sendai (Ishizaki, 1966) and its valves are found in Toyama Bay at depth of $50-300 \mathrm{~m}$ (Ishizaki \& Irizuki, 1990).
Family Leptocytheridae Hanai, 1957

Genus Cluthia Neale, 1973

* Cluthia cluthae Neale, 1973

(Pl. 1, fig. 3)

Remarks. A specimen from the Fujikotogawa Formation resembles Cluthia japonica (Tabuki, 1986) reported from the Pliocene Daishaka Formation, northern Japan, but differs from the latter in having two distinct swellings in the anterocentral area. This species is distributed in Recent sediments of the northwestern Atlantic to Arctic and its fossils were reported around Great Britain (Neale, 1973). Brouwers (1990) recognized it from the middle sublittoral zone of the northeast Gulf of Alaska.

Family Cytheridae Baird, 1850

Genus Palmenella Hirschmann, 1916

* Palmenella limicola (Norman, 1865)

(PI. 1, fig. 4)

Remarks. This species shows no morphological differences between the North Pacific and North Atlantic.

Family Hemicytheridae Puri, 1953 Genus Hemicythere Sars, 1925

* Hemicythere emarginata (Sars, 1865)

(Pl. 1, fig. 7)

Remarks. Hazel (1967) assigned this species to the genus Baffinicythere, but Horne \& Whittaker (1983) suggested that emarginata should come under the genus Hemicythere because it has cospicuous ductus ejaculatorius and two frontal muscle scars as opposed to three in Baffinicythere. Specimens from the Fujikotogawa Formation have more rectangulate valves, each with a less conspicuous vertical rim in the dorsal portion.

\section{+ Hemicythere aff. gurjanovae Schornikov, 1974}

(Pl. 1, figs 5, 6)

Remarks. Cronin \& Ikeya (1987) recognized this species in some Plio-Pleistocene formations of northern Japan. Hemicythere gurjanovae from the intertidal zone of the Kuril Islands (Schornikov, 1974) differs in having robust anterior and posterior rims.

+ Hemicythere kitanipponica (Tabuki, 1986) (Pl. 1, figs 8, 9)

Remarks. Tabuki (1986) assigned this species to the genus Ambostracon, but Hemicythere seems more appropiate because it has two frontal muscle scars and normal and marginal pore patterns similar to some species of the genus Hemicythere (e.g. $H$. emarginata and $H$. orientalis

\section{Explanation of Plate 1}

Fig. 1. Kotoracythere sp., adult left valve, IGPS 102287, FC-12, $\times 75$. Fig. 2. Munseyella hatatatensis Ishizaki, 1966, adult right valve, IGPS 102288, FC-12, $\times 75$. Fig. 3. Cluthia cluthae Neale, 1973, adult left valve, IGPS 102289, FC-14, $\times 123$. Fig. 4. Palmenella limicola (Norman. 1863), adult left valve, IGPS 102290, FC-11, ×70. Figs 5, 6. Hemicythere aff. gurjanovae Schornikov, 1974: fig. 5, adult left valve, IGPS 102291, FC-13, $\times 58$; fig. 6 , adult right vavle, IGPS 102292, FC-12, ×58. Fig. 7. Hemicythere emarginata (Sars, 1865), female left valve, IGPS 102293 , FC-13, $\times 57$. Figs 8, 9. Hemicythere kitanipponica (Tabuki, 1986): fig. 8, adult left valve, IGPS 102294, FC-14, $\times 68$; fig. 9, adult right valve, IGPS 102295, FC-14, ×68. Fig. 10. Hemicythere ochotensis Schornikov, 1974, adult right valve, IGPS 102296, FC-12, $\times 58$ Fig. 11. Baffinicythere sp. 2, juvenile left valve, IGPS $102297, \mathrm{FC}-11, \times 55$. Fig. 12. Elofsonella concinna (Jones, 1857), juvenile left valve, IGPS 102298, FC-12, ×76 Fig. 13. Finmarchinella daishakaensis Tabuki, 1986, juvenile right valve, IGPS 102299, FC-11, ×89. Fig. 14. Finmarchinella hanaii Okada, 1979, female left valve, IGPS 102300, FC-14, $\times 68$. Fig. 15. Finmarchinella japonica (Ishizaki, 1966), male left valve, IGPS $102301, \mathrm{FC}-11, \times 68$. 

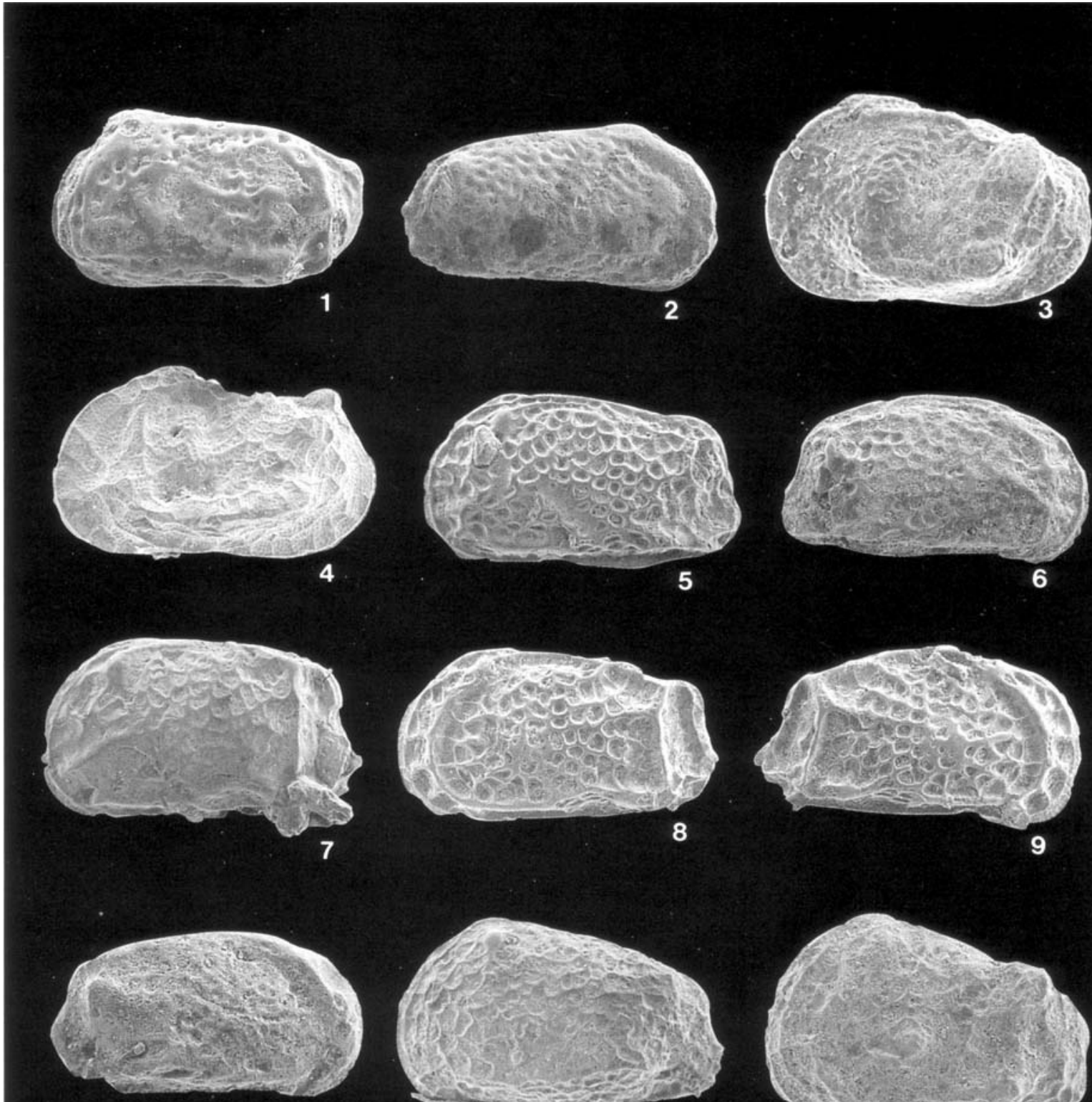

10
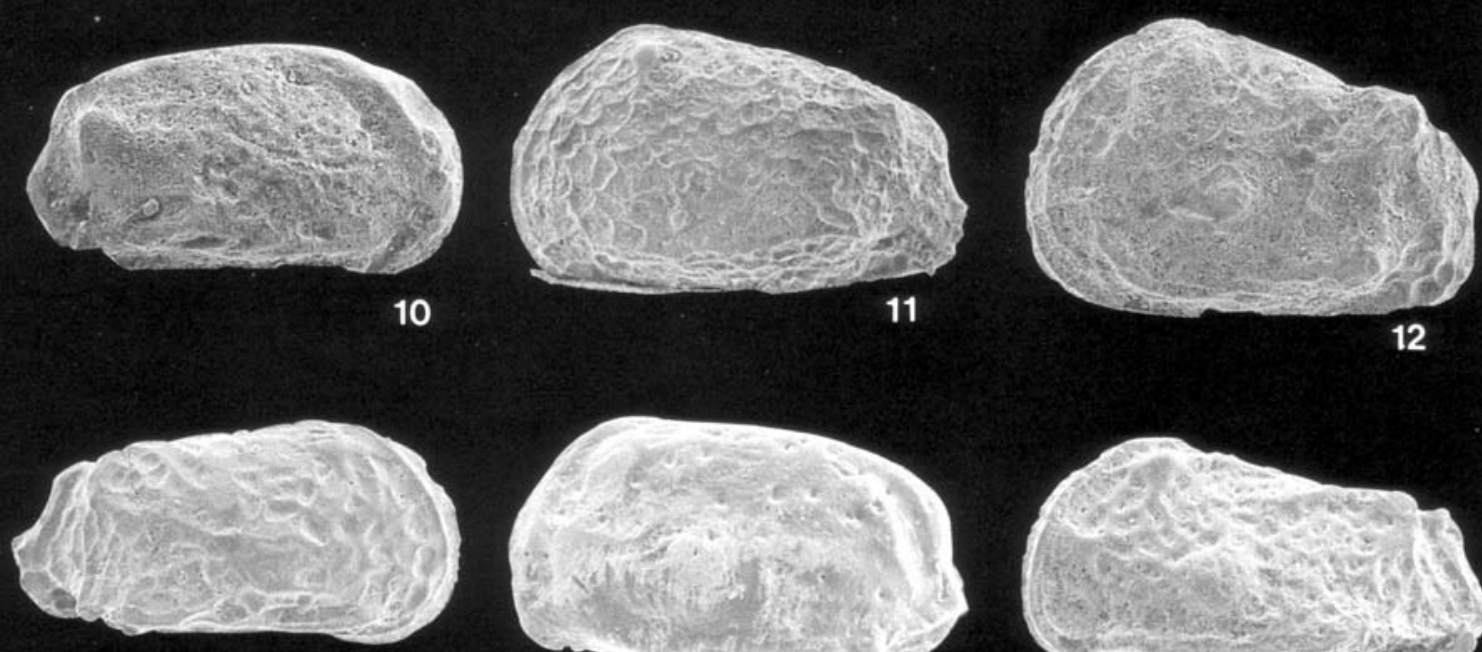

13
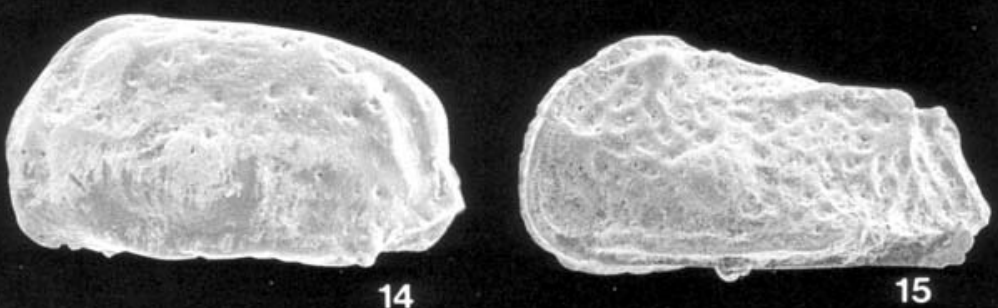
Schornikov) (Irizuki, 1993). Yajima (1988) also recognized this species from the Fujikotogawa Formation as Hemicythere? sp.

\section{+Hemicythere ochotensis Schornikov, 1974}

(Pl. 1, fig. 10)

Remarks. This species resembles Hemicythere quadrinodosa Schornikov, 1974 but the former has a posterior rim as opposed to a tubercle in the latter.

\section{Genus Baffinicythere Hazel, 1967 \\ + Baffinicythere sp. 2}

(Pl. 1, fig. 11)

Remarks. Poorly-preserved specimens from the Fujikotogawa Formation seem to be assigned to Baffinicythere sp. 2 of Irizuki (1993) and Irizuki \& Sasaki (1993). Irizuki (in press) studied reticulation patterns of this species.

Genus Elofsonella Pokorny, 1955

* Elofsonella concinna (Jones, 1856)

(PI. 1, fig. 12)

Remarks. The type specimen of Elofsonella concinna is a pitted form with a conspicuous anterior marginal rim, but specimens from the Fujikotogawa Formation are notably reticulate, with a less conspicuous anterior marginal rim. Bassiouni (1965) assigned pitted and reticulate forms respectively to $E$. concinna and $E$. neoconcinna, but Hazel (1967) thought that both types are conspecific because of the existence of intermediate forms.

Genus Finmarchinella Swain, 1963

+ Finmarchinella daishakaensis Tabuki, 1986

(PI. 1, fig. 13)

Remarks. This species was first described from the Plio-Pleistocene Daishaka Formation by Tabuki (1986). Only juvenile specimens were found in the Fujikotogawa Formation.

\section{+ Finmarchinella hanaii Okada, 1979}

(PI. 1, fig. 14)

Remarks. This species has widely been reported from Plio-Pleistocene formations yielding the Omma Manganji Fauna. Its valves are recognized in shallow sediments from the Sea of Japan around the Noto Peninsula (Irizuki, 1989a).

\section{* Finmarchinella japonica (Ishizaki, 1966)}

$$
\text { (Pl. 1, fig. 15) }
$$

Remarks. This differs from $F$. angulata (Sars) in having an anterior tubercle and more prominent posterior nodes. It is a matter of argument, however, whether these differences of characters represent intraspecific variation or geographically separate subspecies, which is now being studied by the author.

Genus Patagonacythere Hartmann, 1962

- Patagonacythere sasaokensis Irizuki, 1993

(PI. 2, fig. 1)

Remarks. This species was reported by Irizuki (1989b) from the Pliocene Sasaoka Formation, northern Japan as Urocythereis? sp. B. Irizuki (1993) studied pore distributional patterns of this species.

Genus Urocythereis Ruggieri, 1950

- Urocythereis? gorokuensis Ishizaki, 1966

(Pl. 2, fig. 2)

Remarks. This species was first described from the Pliocene Tatsunokuchi Formation in northern Japan ( $\mathrm{g}$ in Fig. 1), where the Tatsunokuchi Fauna, applied to cold shallow water molluscan assemblages in the Japanese Pliocene on the Pacific side, was reported (Nomura, 1938; Otuka, 1941). It was also found in abundance in Plio-Pleistocene formations yielding the Omma-Manganji Fauna.

Family Trachyleberididae Sylvester-Bradley, 1948

Genus Acanthocythereis Howe, 1963

* Acanthocythereis dunelmensis (Norman, 1865) (Pl. 2, fig. 3)

Remarks. Specimens from the Fujikotogawa Formation have more rectangular valves, but the distributional patterns of spines and tubercles are the same as those from the Atlantic.

Genus Robertsonites Swain, 1963

+ Robertsonites hanaii Tabuki, 1986

(Pl. 2, fig. 7)

Remarks. Specimens from the Fujikotogawa Formation are all juveniles. This species differs from $R$. reticuliforma Ishizaki in having a subcentral tubercle and ridges, and its valve is less protrudent toward the posterior than the latter.

+ Robertsonites reticuliforma (Ishizaki, 1966)

(PI. 2, figs 4-6)

Remarks. This species was first described by Ishizaki (1966) from the middle Miocene Hatatate Formation.

Family Cytheruridae Muller, 1894

Genus Hemicytherura Elofson, 1941

Explanation of Plate 2

Fig. 1. Patagonacythere sasaokensis Irizuki, 1993, juvenile left valve, IGPS 102302 , FC-11, $\times 52$ Fig. 2. Urocythereis? gorokuensis Ishizaki, 1966 , juvenile lcft valve, IGPS 102303, FC-11, ×71. Fig. 3. Acanthocythereis dunelmensis (Norman, 1865), female right valve, IGPS 102304, FC-15, $\times 40$. Figs 4-6. Robertsonites reticuliforma (Ishizaki, 1966); fig. 4, juvenile right valve, IGPS 102305 , FC-15, $\times 60$; fig. 5, female left valve, IGPS 102306, FC-13, $\times 49$; fig. 6, female right valve, IGPS 102307, FC-14, ×49. Fig. 7. Robertsonites hanaii Tabuki, 1986, juvenile right valve, IGPS 102308 , FC-12, $\times 85$. Fig. 8. Hemicytherura clathrata (Sars, 1866), adult left valve, IGPS 102309 , FC $-14, \times 80$. Fig. 9. Semicytherura mainensis Hazel \& Valentine, 1969, adult left valve, IGPS 102310, FC-14, $\times 80$. Figs 10, 11. Howeina neoleptocytheroidea (Ishizaki, 1966); fig. 10, adult left valve, IGPS 102311, FC-11, $\times 73$; fig. 11, adult right valve, IGPS 102312, FC-11, $\times 73$. Fig. 12. Cytheropteron cf. angulatum Brady \& Robertson, 1872, adult left valve, IGPS 102313, FC-14, $\times 86$. Fig. 13. Cytheropteron cf. arcticum Neale \& Howe, 1973, juvenile left valve, IGPS 102314. FC-11, $\times 82$. Fig. 14. Cytheropteron cf. nodosoalatum Neale \& Howe, 1973, juvenile right valve, IGPS 102315, FC-12, $\times 72$. Fig. 15 . Cytheropteron sawanense Hanai, 1957, adult left valve, IGPS 102316, FC-14, $\times 82$. 


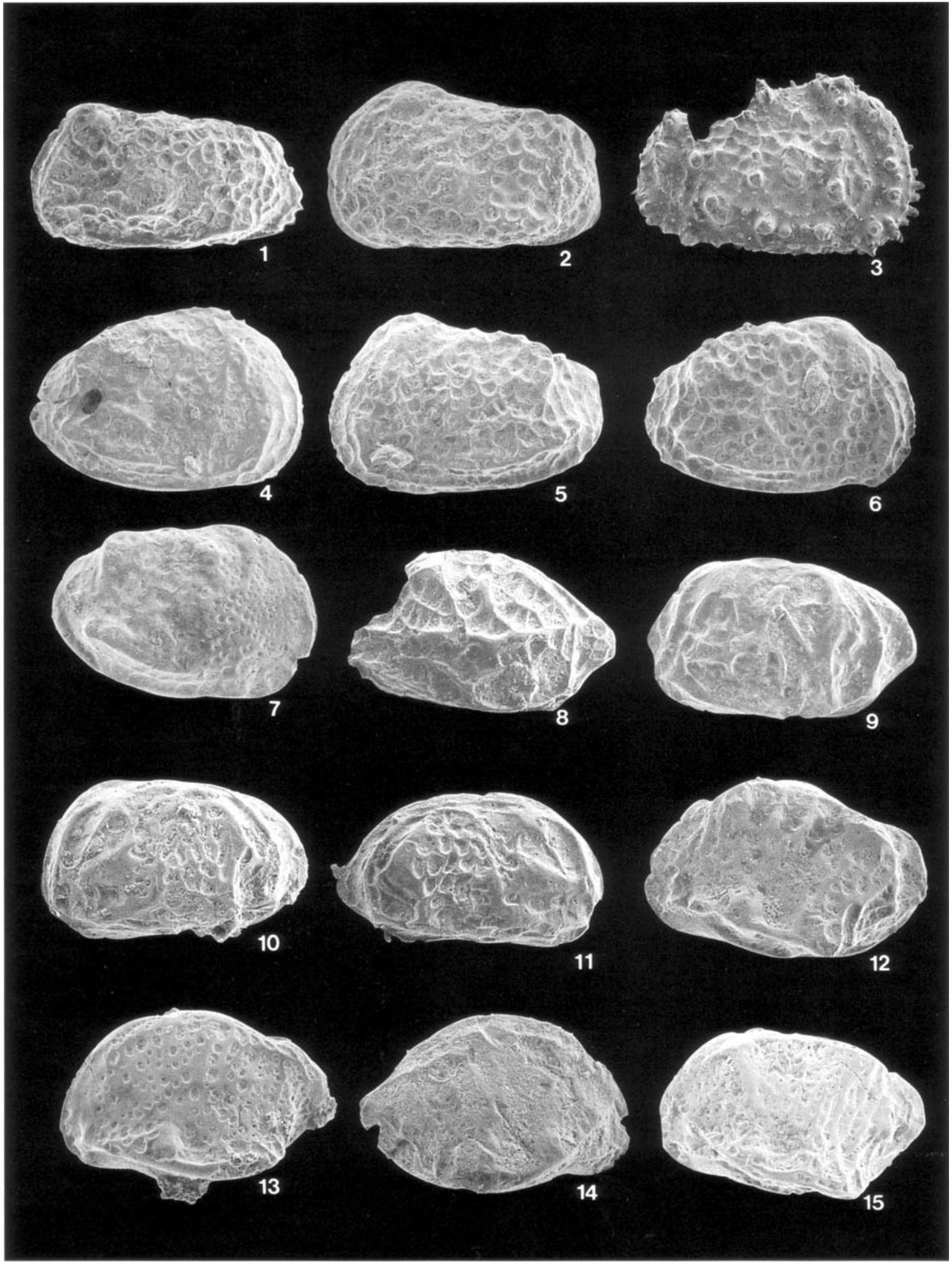




\section{* Hemicytherura clathrata (Sars, 1865)}

(Pl. 2, fig. 8)

Remarks. This has been well illustrated by Neale \& Howe (1975) and Hartmann (1992). Specimens from the Fujikotogawa Formation and those from the Atlantic have the same reticular and ridge patterns.

Genus Howeina Hanai, 1957

- Howeina neoleptocytheroidea (Ishizaki, 1966)

(Pl. 2, figs 10,11)

Remarks. This was first described from the Pliocene Tatsunokuchi Formation mentioned above. It is closely related to Semicytherura mainensis.

Genus Semicytherura Wagner, 1957

* Semicytherura mainensis Hazel \& Valentine, 1969 (Pl. 2, fig. 9)

Remarks. Specimens from the Fujikotogawa Formation have less conspicuous reticulation and subcentral tubercle than the type specimens but their ridge patterns are very similar. They also resemble Howeina higashimeyaensis Ishizaki, 1971, of which type specimens have prominent vertical ridges in the posterior portion, but have curved ridges. According to Hazel \& Valentine (1969) and Siddiqui \& Grigg (1975), this species ranges from the Pleistocene to Recent around Nova Scotia, eastern Canada and USA.

* Semicytherura subundata Hanai, 1957

(Pl. 3, figs. 4, 5)

Remarks. Most species of the genus Semicytherura from the Fujikotogawa Formation are morphologically related to the $S$. undata-S. subundata group (see Pl. 3, figs 1-17). Semicytherura subundata is characterized by its large valve size and robust ridges. Cronin recognized this species in the Pleistocene of northeastern North America (Cronin \& Ikeya, 1987).

Genus Cytheropteron Sars, 1865

* Cytheropteron cf. angulatum Brady \& Robertson, 1872 (Pl. 2, fig. 12)

Remarks. Specimens from the Fujikotogawa Formation have less prominent tubercles on the ala than the type specimens. Tabuki (1986) also reported this species from the Plio-Pleistocene Daishaka Formation (Cytheropteron tsugaruense). According to Whatley \& Masson (1979), this species ranges from the Pleistocene to Recent in the Arctic and north Atlantic, and Recent specimens occur in boreal, sub-Arctic and Arctic waters on both sides of the
Atlantic (15 to 142 fathoms in depth). According to Brouwers' data, this species is also living in the southwestern Gulf of Alaska.

* Cytheropteron cf. arcticum Neale \& Howe, 1973

(Pl. 2, fig. 13)

Remarks. The type specimens of $C$. arcticum have fine pitted ornamentation; specimens from the Fujikotogawa Formation have much coarser ornamentation. According to Neale \& Howe (1973), this species ranges from the late Pleistocene (Hoxinian) to Recent in Europe. Recent specimens occur in some abundance at Russian Harbour, Novaya Zemlya and at $71^{\circ} 15.0^{\prime} \mathrm{N}, 27^{\circ} 54.0^{\prime} \mathrm{E}$ (142 fathoms).

* Cytheropteron cf. nodosoalatum Neale \& Howe, 1973 (PI. 2, fig. 14)

Remarks. A poorly-preserved specimen from the Fujikotogawa Formation resembles the juvenile specimen (paratype) of Neale \& Howe (1975).

\section{- Cytheropteron sawanense Hanai, 1957}

(Pl. 2, fig. 15)

Remarks. This species has been widely recognized in Plio-Pleistocene formations yielding the Omma-Manganji Fauna in northern Japan (e.g. Hanai, 1957c).

\section{ACKNOWLEDGEMENTS}

The author expresses his deep gratitude to Professor Kunihiro Ishizaki of the Department of Geoenvironmental Science, Faculty of Science, Tohoku University, for advice and continuous encouragement throughout the course of the present study and critical reading of the manuscript. Deep appreciations are also expressed to Emeritus Professor Yokichi Takayanagi and Professor Tsunemasa Saito of the same university for their assistance, suggestions and discussions concerning various aspects of the study, and reading of the manuscript. The author is indebted to Dr Thomas M. Cronin of the US Geological Survey for constructive discussions and suggestions about North Atlantic ostracod assemblages. Sincere thanks are also due to Professor Kenshiro Ogasawara of Tsukuba University for constructive suggestions concerning the Omma-Manganji Fauna. Acknowledgements are also due to Shohei Otomo and Jun Nemoto of the Department of Geoenvironmental Science, Faculty of Science, Tohoku University, for their photographic assistance. A part of this study is supported financially by the Katayama Memorial Scholarship from Tohoku University.

\section{Explanation of Plate 3}

Figs 1, 2. Semicytherura henryhowei Hanai \& Ikeya, 1982: fig. 1, adult left valve, IGPS 102317, FC-14, ×108; fig. 2, adult right valve, IGPS 102318, FC-14, $\times 108$

Fig. 3. Semicytherura aff. henryhowei Hanai \& Ikeya, 1982, adult? left valve, IGPS 102319, FC-12, X99. Figs 4, 5. Semicytherura subundata (Hanai, 1957): fig. 4, left exterior view of juvenile? carapace, IGPS 102320, FC-12, $\times 88$; fig. 5, juvenile? right valve, IGPS 102321, FC-14, $\times 88$. Fig. 6. Semicytherura sp. 1, adult? left valve, IGPS 102322, FC-12, $\times 110$. Fig. 7. Semicytherura sp. 2, adult? left valve, IGPS 102323, FC-15, $\times 120$. 7Figs $8-11$. Semicytherura sp. 3: fig. 8, male left valve, IGPS 102324, FC-13, $\times 97$; fig. 9, male right valve, IGPS 102325 , FC-13, $\times 97$; fig. 10, female left valve, IGPS 102326, FC-15, ×97; fig. 11, female right valve, IGPS 102327, FC-15, ×97. Figs 12-15. Semicytherura sp. 4: fig. 12, male left valve, IGPS 102328, FC-11, ×94; fig. 13, male right valve, IGPS 102329, FC-11, $\times 94$; fig. 14, female left valve, IGPS 102330, FC-11, $\times 94$; fig. 15, female right valve, IGPS $102331, \mathrm{FC}-12, \times 94$. Figs 16,17 . Semicytherura sp. 5 : fig. 16, adult left valve, IGPS 102332 , FC-14, $\times 120$; fig. 17. adult right valve, IGPS 102333, FC-14, $\times 120$. Fig. 18 . Semicytherura sp. 6 , juvenile right valve, IGPS 102334, FC-13, $\times 133$. 


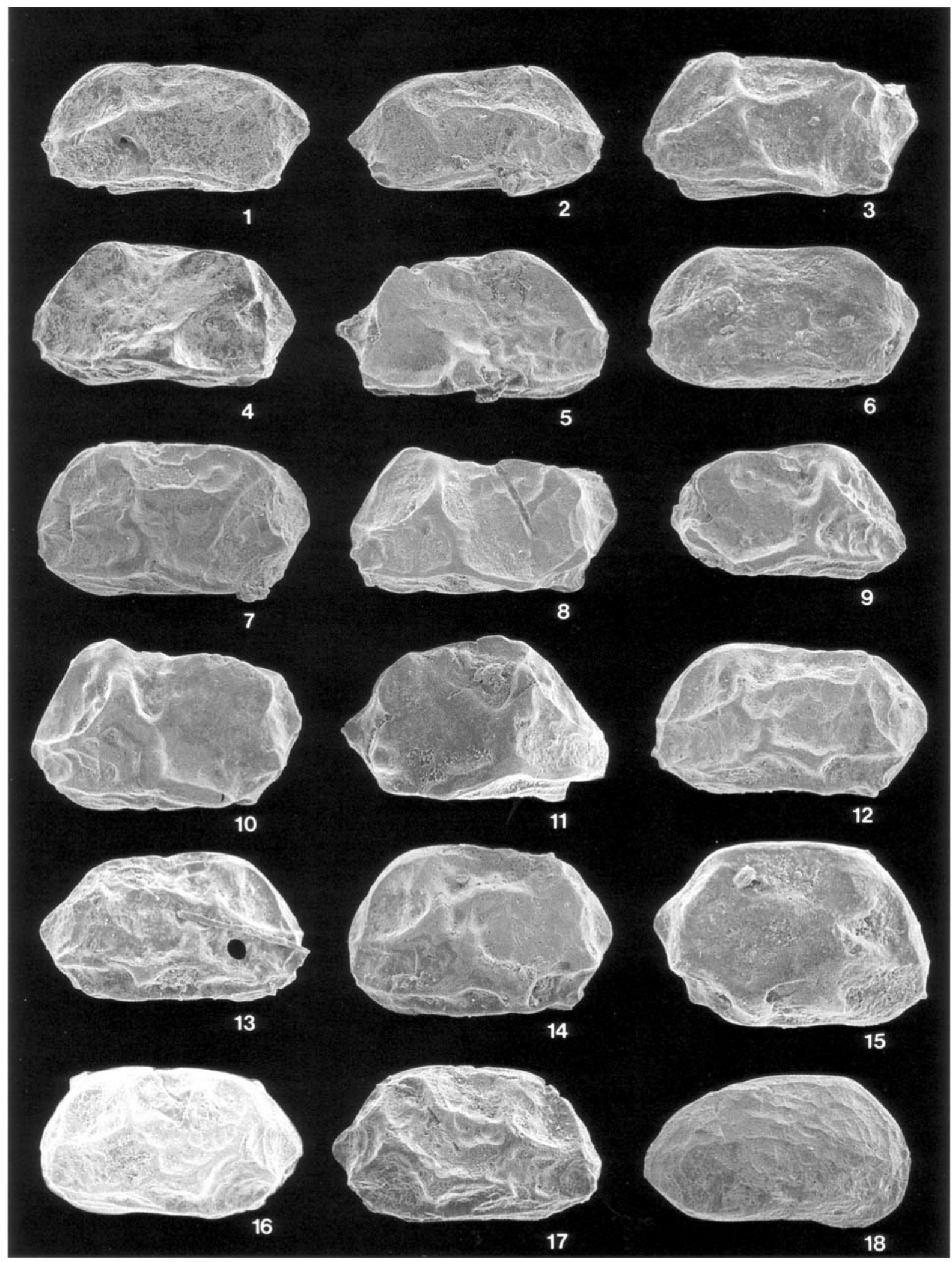




\section{Manuscript received July 1992 Manuscript accepted October 1993}

\section{Addendum}

Irizuki \& Matsubara (1994) reported six circumpolar ostracod taxa (Acanthocythereis dunelmensis, Elofsonella cf. concinna, Finmarchinella japonica, Hemicytherura clathrata, Munseyella hatatatensis, and Palmenella limicola) from the early Middle Miocene (c. $16 \mathrm{Ma}$ ) of northern Japan, which, thus far, represent the oldest fossil record of circumpolar species of Japan.

\section{REFERENCES}

Bassiouni, M. A. A. 1965. Über einige Ostracoden aus dem Interglazial von Esbjerg. Meddelelser fra Dansk Geologisk Forening, 15(4): 507-518.

Blow, W. H. 1969. Late Middle Eocene to Recent planktonic foraminiferal biostratigraphy. In Brönniman, P. \& Renz, H. H. (Eds), Proceedings of the first International Conference on Planktonic Microfossils (Geneva, 1967), Vol. 1, 199-421, E. J. Brill, Leiden, Holland.

Brouwers, E. M. 1990. Systematic paleontology of Quaternary ostracode assemblages from the Gulf of Alaska, part 1: Families Cytherellidae, Bairdiidae, Cytheridae, Leptocytheridae, Limnocytheridae, Eucytheridae, Krithidae, Cushmanideidae. US Geological Survey Professional Paper, Washington, 1510: 43 p., 13 pls.

Brouwers, E. M., Jørgensen, N. O. \& Cronin, T. M. 1991. Climatic significance of the ostracode fauna from the Pliocene Kap København Formation, North Greenland. Micropaleontology, New York, 37(3): 245-267, 4 pls.

Buzas, M. A. \& Gibson, T. G. 1969. Species diversity: benthonic Foraminifera in western North Atlantic. Science, 163: 72-75.

Cronin, T. M. 1981. Paleoclimatic implications of Late Pleistocene marine ostracodes from the St. Lawrence Lowlands. Micropaleontology, New York, 27(4): 384-418, 11 pls.

Cronin, T. M. 1988. Evolution of marine climates of the U.S. Atlantic coast during the past four million years. In Shackleton, N. J., West, R. G. \& Bowen, D. Q. (Eds), The Last Three Million Years: Evolution of Climatic Variability in the North Atlantic Region. Philosophical Transactions of the Royal Society (London), Series B, 318(1191); 661-678.

Cronin, T. M. 1991a. Pliocene shallow water paleoceanography of the North Atlantic ocean based on marine ostracodes. Quaternary Science Reviews, 10(2/3): 175-188.

Cronin, T. M. 1991b. Late Neogene marine Ostracoda from Tjörnes Iceland. Journal of Paleontology, Lawrence, 65(5): 767-794.

Cronin, T. M. \& Dowsett, H. J. 1990. A quantitative micropaleontologic method for shallow marine palcoclimatology: application to Pliocene deposits of the western North Atlantic Occan. Marine Micropaleontology, Amsterdam, 16; 117-147.

Cronin, T. M. \& Ikeya, N. 1987. The Omma-Manganji ostracod fauna (Plio-Pleistocene) of Japan and zoogeography of circumpolar spccies. Journal of Micropalaeontology, London, 6(2); 65-88, 3 pls.

Durham, J. W. \& MacNeil, F. S. 1967. Cenozoic migration of marine Invertebrates through the Bering Strait region. In Hopkins, M. D. (Ed.), The Bering Land Bridge, 326-349, Stanford University Press, Stanford, California.

Gladenkov, Y. B. 1981. Marine Plio-Pleistocene of Iccland and problems of its correlation. Quaternary Research, 15: 18-23.

Gladenkov, Y. B., Barinov, K. B., Basilian, A. E. \& Cronin, T. M. 1991. Stratigraphy and paleoccanography of Pliocene deposits of Karaginsky Island, eastern Kamchatka, U.S.S.R. Quaternary Science Reviews, 10(2/3): 239-245.

Hanai, T. 1957a. Studies on the Ostracoda from Japan, I. Subfamily Leptocytherinae, n. subfam. Journal of the Faculty of Science, University of Tokyo, sec $2, \mathbf{1 0}(3): 431-468$, pls 7-10.
Hanai, T. 1957b. Studies on the Ostracoda from Japan, II Subfamily Pectocytherinac n. subfam. Journal of the Faculty of Science, University of Tokyo, sec 2, 10(3): 469-482, pl. 11.

Hanai, T. 1957c. Studies on the Ostracoda from Japan, III. Subfamilies Cytherurinae G. W. Müller (emend. G. O. Sars, 1925) and Cytheropterinae n. subfam. Journal of the Faculty of Science, University of Tokyo, sec 2, 11(1): 11-36, pls 2-4.

Hanai, T. 1959a. Studies on the Ostracoda from Japan, IV. Family Cytherideidae Sars, 1925. Journal of the Faculty of Science, University of Tokyo, sec 2, 11(3): 291-308, pls 16-18.

Hanai, T. 1959b. Studies on the Ostracoda from Japan, V. Subfamily Cytherinae Dana, 1852 (emend.). Journal of the Faculty of Science, University of Tokyo, sec 2, 11(4): 409-418, pl. 28 .

Hanai, T. 1970. Studies on the ostracod subfamily Schizocytherinae Mandelstam. Journal of Paleontology, Chicago, 44(4): 693-729, pls 107, 108.

Hanai, T. \& Yamaguchi, T. 1987. Plio-Pleistocene ostracod fauna of Shimokita, Aomori Prefecture (preliminary Report). Memoirs of the National Science Museum, Tokyo, 20: 45-51 (Japanese, English summary).

Hartmann, G. 1992. Zur Kenntnis der rezenten und subfossilen Ostracoden des Liefdefjords (Nordspitzbergen, Svålbard). I. Teil. Mit einer Tabelle subfossil nachgewiesener Foraminiferen. Mitteilungen aus dem Hamburgischen Zoologischen Museum und Institut, Hamburg, 89: 185-225, 8 pls.

Hayashi, K. 1988. Plio-Pleistocene paleoenvironment and fossil ostracod fauna from southwestern Hokkaido, Japan. In Hanai, T., Ikeya, N. \& Ishizaki, K. (Eds), Evolutionary biology of Ostracoda, its fundamentals and applications, 557-567, Kodansha Ltd., Tokyo and Elsevier, Amsterdam, Oxford, New York, Tokyo.

Hazel, J. E. 1967. Classification and distribution of the Recent Hemicytheridac and Trachyleberididae (Ostracoda) off northeastern North America. US Geological Survey Professional Paper, Washington, 564: 49 p., 11 pls.

Hazel, J. E. 1968. Pleistocene ostracode zoogeography in Atlantic coast submarine canyons. Journal of Paleontology, Chicago, 42(5): 1264-1271.

Hazel, J. E. 1970. Atlantic continental shelf and slope of the United States-Ostracode zoogeography in the southern Nova Scotian and northern Virginian faunal provinces. US Geological Survey Professional Paper, Washington, 529-E, 21 p., 69 pls.

Hazel, J. E. \& Valentine, P. C. 1969. Three new ostracodes from off northeast North America. Journal of Paleontology, Chicago, 43(3): 741-752, pls 97,98 .

Horne, D. J. \& Whittaker, J. E. 1983. On Baffinicythere howei Hazel. Stereo Atlas of Ostracod Shells, London, 10(9): 53-62.

Ikeya, N. \& Itoh, H. 1991. Recent Ostracoda from the Sendai Bay region, Pacific coast of northeastern Japan. Reports of Faculty of Science, Shizuoka University, 25; 93-145.

Ikeya, N. \& Suzuki, C. 1992. Distributional patterns of modern ostracodes off Shimane Peninsula, southwestern Japan Sea. Reports of the Faculty of Science, Shizuoka University, 26: 91-137, 9 pls.

Irizuki, T. 1989a. Recent ostracod assemblages off the Noto Peninsula and in Toyama Bay. In Arita, M. \& Okamura, Y. (Eds), Research on submarine geology of the continental shelf around southwest Japan.-around the Noto Peninsula-, 138-144, Geological Survey of Japan, Tsukuba (Japanese, title translated).

Irizuki, T. 1989b. Fossil ostracode assemblages from the Pliocene Sasaoka Formation, Akita City, Japan-with reference to sedimentological aspects - . Transactions and Proceedings of the Palaeontological Society of Japan, New Series, 156: 296-318.

Irizuki, T. 1993. Morphology and taxonomy of some Japanese hemicytherin Ostracoda - with particular reference to ontogenetic changes of marginal pores -. Transactions and Proceedings of the Palaeontological Society of Japan, New Series, 170: 186-211.

Irizuki, T. (in press). Quantitative analysis of ontogenetic changes 
of cell-reflecting sculptures in Ostracoda (Crustacea). Journal of Paleontology, Lawrence.

Irizuki, T. (in prep.) Ontogenetic changes and heterochrony in three species of the genus Baffinicythere (Ostracoda, Crustacea), northern Japan.

Irizuki, T. \& Matsubara, T. 1994. Vertical changes of depositional environments of the Lower to Middle Miocene Kadonosawa Formation based on analyses of fossil ostracode faunas. The Journal of the Geological Society of Japan, 100(2): 136-149, $1 \mathrm{pl}$. (Japanese, English abstract).

Irizuki, T. \& Sasaki, O. 1993. Analysis of morphological changes through ontogeny: genera Baffinicythere and Elofsonella (Hemicytherinae). In McKenzie, K. G. \& Jones, P. J. (Eds), Ostracoda in the Earth and Life Sciences, 335-350, Balkema, Rotterdam.

Ishizaki, K. 1966. Miocene and Pliocene ostracodes from the Sendai area. Science Reports of the Tohoku University, Second Series (Geology), 37(2): 131-163, pls 16-19.

Ishizaki, K. 1979. Study of Ostracoda from the Pliocene Ananai Formation, Shikoku, Japan - a step toward distinguishing the sedimentary environments -. In Serbian Geological Society (Eds), Taxonomy, Biostratigraphy and Distribution of Ostracodes, 197-205, Beograd.

Ishizaki, K. \& Irizuki, T. 1990. Distribution of bathyal ostracodes in sediments of Toyama Bay, Central Japan. Courier Forschungsinstitut Senckenberg, Frankfurt a. M., 123: 53-67, 1 pl.

Ishizaki, K. \& Matoba, Y. 1985. Akita (Early Pleistocene cold, shallow water Ostracoda). Guidebook of excursions 5: 9 th International Symposium on Ostracoda, July 29-August 2, 1985 , Shizuoka, Japan, 12 p., 8 pls.

Ishizaki, K. \& Tanimura, Y. 1985. Ostracoda from the Pliocene Ananai Formation, Shikoku, Japan-faunal analyses-. Transactions and Proceedings of the Palaeontological Society of Japan, New Series, 137: 50-63.

Ishizaki, K., Irizuki, T. \& Sasaki, O. 1993. Cobb Mountain spike of the Kuroshio Current detected by Ostracoda in the lower Omma Formation (Pleistocene), Kanazawa City, central Japan Analysis of depositional environments -. In McKenzie, K. G. \& Jones, P. J. (Eds), Ostracoda in the Earth and Life Sciences, 315-334, Balkema, Rotterdam.

MacNeil, F. S. 1973. Arctic and boreal climate at the beginning of the Pleistocene. Science Reports of the Tohoku University, Second Series (Geology.), Special Volume, 6 (Hatai Memorial Volume): 55-57.

Marincovich, L. Jr., Brouwers, E. M., Hopkins, D. M. \& McKenna, M. C. 1990. Late Mesozoic and Cenozoic paleogeographic and paleoclimatic history of the Arctic Ocean Basin, based on shallow-water marine faunas and terrestrial vertebrates. In Grantz, A., Johnson, L. \& Sweeney, J. F. (Eds), The Geology of North America Vol. L, The Arctic Ocean region, 403-426, Geological Society of America, Boulder, Colorado.

Neale, J. W. 1973. Cluthia (Crustacea, Ostracoda), a new Pleistocene and Recent Leptocytherid genus. Journal of Paleontology, Chicago, 47(4): 683-688, 1 pl.

Neale, J. W. \& Howe, H. V. 1973. New cold water Recent and Pleistocene species of the ostracod genus Cytheropteron. Crustaceana, E. J. Brill, Leiden, 25(3): 237-244, 1 pl.

Neale, J. W. \& Howe, H. V. 1975. The marine Ostracoda of Russian Harbour, Novaya Zemlya and other high latitude faunas. Bulletins of American Paleontology, Ithaca, 65(282); 381-431, 7 pls.

Nomura, S. 1938. Molluscan fossils from the Tatunokuchi shell bed exposed at Goroku cliff in the western border of Sendai. Science Report of the Tohoku University, Second Series (Geology), 18(2): 235-275, pls 33-36.

Ogasawara, K. 1986. Notes on origin and migration of the Omma-Manganzian fauna, Japan. Palaeontological Society of Japan, Special Paper, 29: 227-244.

Ogasawara, K., Oda, M. \& Horikoshi, E. 1986. Route No. 14. In Kitamura, N. (Ed.), Collected geological data on the Cenozoic of northeast Honshu, Japan, 2(2); 1-21, Hobundo Company, Japan (Japanese).

Okada, H. \& Bukry, D., 1980. Supplementary modification and introduction of code numbers to the low-latitude coccolith biostratigraphic zonation (Bukry, 1973; 1975). Marine Micropaleontology, Amsterdam, 5: 321-325.

Okada, Y. 1979. Stratigraphy and Ostracoda from the Late Cenozoic strata of the Oga Peninsula, Akita Prefecture. Transactions and Proceedings of the Palaeontological Society of Japan, New Series, 115: 143-173, 2 pls.

Otuka, Y. 1939. Tertiary crustal deformation in Japan (with short remarks on Tertiary paleography). Jubilee publication in the commemoration of Professor. H. Yabe, M.I.A. sixtieth birthday 1, Commemorative Association of Professor H. Yabe's Sixtieth Birthday, Sendai, 481-519.

Otuka, Y. 1941. Tertiary fossil fauna found the area between Honjo and Kurosawajiri. Journal of the Japanese Association for Petroleum Technology, 9: 147-157, 1 pl. (Japanese, title translated).

Penney, D. N. 1989. Recent shallow marine Ostracoda of the Ikerssuak (Bredefjord) District, Southwest Greeland. Journal of Micropalaeontology, London, 8(1); 55-75, 3 pls.

Saito, T. \& lzawa, T. 1988. Fossil planktonic foraminiferal assemblages from the upper Miocene in northeastern Japan and their paleobiogeographic significance. Abstracts of the 137th regular meeting of the Palaeontological Society of Japan, 16 (Japanese, title translated).

Schornikov, E. I. 1974. On the study of Ostracoda (Crustacea) from the intertidal of the Kurile Islands. Sbornik Rabot, Institut Biologii Morya, Dalnevostochnyy Nauchnyy Isentr., Akademya Nauk SSSR, 1: 137-214 (Russian, English abstract).

Siddiqui, Q. A. \& Grigg, U. M. 1975. A preliminary survey of the ostracodes of Halifax Inlet. Bulletins of American Paleontology, Ithaca, 65(282): 369-379, 2 pls.

Sumi, K. \& Moritani, T. 1973. Geology of the Yonaizawa District. Quadrangle series, scale 1: 50,000, Aomori (5), (53), 46 p., 7 pls, 1 map. Geological Survey of Japan (Japanese, English abstract).

Swain, F. M. 1963. Pleistocene Ostracoda from the Gubik Formation, Arctic coastal plain. Alaska. Journal of Paleontology, Chicago, 37(4): 798-834, pis 95-99.

Tabuki, R. 1986. Plio-Pleistocene Ostracoda from the Tsugaru Basin, north Honshu, Japan. Bulletin of College of Education University of the Ryukyus, 29(2): 27-160, 20 pls.

Vermeij, G. J. 1991. Anatomy of an invasion: the trans-Arctic interchange. Paleobiology, Ithaca, 17(3): 281-307.

Whatley, R. C. \& Masson, D. G. 1979. The ostracod genus Cytheropteron from the Quaternary and Recent of Great Britain. Revista Española de Micropaleontologia, Madrid, 11(2): 223-277, 8 pls.

Yajima, M. 1988. Preliminary notes on the Japanese Miocene Ostracoda. In Hanai, T., Ikeya, N. \& Ishizaki, K. (Eds), Evolutionary biology of Ostracoda-its fundamentals and applications, 1073-1085, 2 pls, Kodansha Ltd., Tokyo and Elsevier, Amsterdam, Oxford, New York, Tokyo. 